\title{
ESSAY
}

\section{ON THE MORAL OBLIGATION TO OBEY THE LAW}

\author{
George C. Christie*
}

\section{INTRODUCTION}

The principal arguments used by skeptics to establish that there is no general moral obligation to obey the law-not even a prima facie obligation-can also be used to establisli that there is no general moral obhgation to obey any particular moral norm. Perliaps no such general moral obligations exist-a conclusion I personally am not presently prepared to accept-but this conclusion is not what the skeptics think that they have shown. Indeed, these individuals believe that there are general moral obligations. Their point rather is that, unlike our general moral obligation to obey particular moral norms, we have no such obligation with regard to legal norms, not even a prima facie obligation.

I state my thesis starkly, in order to focus the mind of the reader, because it will be necessary to discuss a number of preliminary matters before I can directly address my principal contention. These preliminary matters are sufficiently important to require more attention than would be necessary if their only significance were their contribution to my central thesis.

Impelled undoubtedly by the turmoil occasioned by the Vietnam War, for almost twenty years there has been a vast outpouring of literature on the subject of the moral obligation to obey the law. Many of the participants in the debate liave returned to the subject agam and agam. ${ }^{1}$

* James B. Duke Professor of Law, Duke University School of Law. A preliminary version of this Essay was presented to the Columbia Legal Theory Workshop on Noveniber 21, 1988. I am indebted to the participants at the workshop for their helpful comments. I should also like to thank Martin P. Golding, Donald H. Regan, George W. Roberts, and Martin Stone for their helpful contments as well.

1. See, e.g., J. Raz, The Authority Of LAW: Essays ON LAW AND Morality 233-89 (1979) [hereinafter J. RAZ, AUTHORITY] (arguing that, despite moral and practical reasons to obey the law in certain instances, no general moral obhigation to obey the law exists); A. S1Mmons, Moral Principles ANd Political Obligations (1979) [hereinafter A. SImMons, MoRal PRINCIPLES] (discussing categories of obligations and the importance of institutional requirements, but denying that the existence of an institutional obligation establishes the existence of a inoral obliga- 
Almost all the participants have started from the observation that the average person in the Western world accepts that one has a general moral obligation to obey the law, or, at the very least, the participants im the debate have been prepared to assuine that this is so. ${ }^{2}$

To simplify the discussion, I shall adopt John Simmons' practice of speaking of a moral obligation to obey the law, rather than of a prima facie moral obligation to obey the law. ${ }^{3}$ Following this practice, to say that one has a moral obligation to obey the law does not mean that one must necessarily obey the law. Other inore important countervailing moral obligations nay require that one not obey the law. Although the obligation to obey the law remains, it may be outweighed by other relevant moral considerations. Unlike a discussion expressed in terms of prima facie obligations, this analysis does not suggest that overridden moral "obligations" were in fact not obligations. ${ }^{4}$

tion); P. SOPER, A THEORY OF LAW (1984) (legal and moral obligation are separate concepts and one cannot be utilized to define the other); Raz, The Obligation to Obey: Revision and Tradition, 1 Notre Dame J.L. Ethics \& PUB. Pol'y 139 (1984) (general obligation to obey the law can only arise if voluntarily undertaken); Raz, Authority and Consent, 67 VA. L. REv. 103 (1981) (the relationship between the lack of a general moral obligation to obey the law and the problem concerning relations between an individual citizen and the state); Simmons, Voluntarism and Political Assoclations, 67 VA L. REv. 19 (1981) [hereinafter Simmons, Voluntarism 1 (realization of voluntarist ideas of political associations would permit widespread obligations of citizens to obey the law); Simmons, Consent, Free Choice, and Democratic Government, 18 GA. L. REv. 791 (1984) [hereinafter Simmons, Consent $]$ (mere residence in a state does not amount to an act of binding consent to that state); Soper, Legal Theory and the Obligation to Obey, 18 GA. L. REv. 891 (1984) (assumption that one does not need to deeide what the law is before deciding whether there is a moral obligation to obey the law is unwarranted); Soper, The Moral Value of Law, 84 MrCH. L. REv. 63 (1985) (the important factor in determining the existence of a moral obligation to obey the law is whether the responsible officials have acted in good faith).

2. See, e.g., J. RAZ, AUTHORITY, supra note 1, at 235 ("most people believe themselves to be under such an obligation"); A. Simmons, Moral Principles, supra note 1, at 3 ("Many people feel, I think, that they are tied in a special way to their government, not just by 'bonds of affection,' but by moral bonds."); Smith, Is There a Prima Facie Obligation to Obey the Law?, 82 YALE L.J. 950, 975 (1973) ("I am not contending that refleetive and conscientious citizens would, if asked, deny that there is a prima facie obligation to obey the law. Indeed, I am willing to concede that many more would affirm its existence than deny it.").

3. A. Simmons, Moral Principles, supra note 1, at 24-26.

4. Simmons contends, see id., that this usage more nearly captures the sense of what W. D. Ross, the person from whom the phraseology of "prima facie" duties is taken, actually intended. For a discussion of the distinction between "the act that ought to be done" and the "morally good act," see W. D. Ross, The RIGHT AND The Good 3-4, 18-20, $41-47$ (1930). See also W. D. Ross, FouNDATIONS OF ETHICs 42-45 (1939) (analyzing whether "right" or "obligatory" can be defined with reference to some ethical term other than "right"). Kurt Baier suggests an even more finely tuned analysis. He distinguishes among reasons on balance (that is, reasons that something is the right thing to do, all things considered), prima facie reasons (that is, reasons that give rise to a presumption that something is the right thing to do on balance), and presumptive reasons (that is, reasons that give rise to a presumption that something is a prima facie reason). K. BAlER, THE Moral Point Of View: A Rational Basis Of Ethics 102-06 (1958) 


\section{The Basic Philosophical Positions}

A large number of contemporary writers take the position that there is no moral obligation to obey the law. For example, M.B.E. Smith, in an important article published in 1973,5 argued that there cannot be a moral obligation to obey the law. He claimed that such an obligation cannot be derived from more basic inoral obligations such as those of "fair play" or "consent."6 Nor, he contended, is such an obligation necessary to ensure the effectiveness of the legal system. Whetlier one attempts to base the moral obligation to obey the law on considerations of fair play, gratitude, or utility, there are many situations in which one's failure to obey the law will neitlier cause inconvenience nor-because the failure to obey the law goes unobserved-set a bad example. Smitl provides, by way of illustration, the example of a person who runs a stop light or a stop sigu late at night. ${ }^{7}$ Whatever moral obligations one may liave to stop at red lights come not from law, or the moral obligation to obey the law, but froin the requirenients of social coordination.

Donald Regan, an exponent of a type of act-utilitariamism, uses the same illustration in constructing his argument that there is no general moral obligation to obey the law. ${ }^{8}$ Regan's thesis is complex. He does not deny that law frequently is pronulgated with the idea of generating moral obligations nor does he deny that on many occasions laws do in fact create inoral obligations. Indeed, he leaves open the possibility that im a society of samts, i.e., a perfect society, the identity between legal obligation and moral obligation may be so complete that people might be tempted to speak of law as imposing moral obligations because law itself is constitutive of that just society. ${ }^{9}$ Regan's point is merely that one's recognition of a legal obligation to behave in sone particular manner does not entail that one has a moral obligation to behave in that manner. In other words, altliough on many occasions our moral obligations may coincide with our legal obligations, something is not a moral obligation simply because it is a legal obligation.

Neitlier Smith nor Regan seems prepared to take seriously the assertion that failure to obey the law, even if not harmful to others nor witnessed by others, is nonetlieless harmful to the law-breaker himself, in

\section{Smith, supra note 2.}

6. Id. at $953-69$.

7. Id. at 958, 971. Presumably, to be so sure that no one might be affected by a bad example, the night must be very clear and one must be driving alone, or perhaps only with philosophers.

8. Regan, Law's Halo, Soc. PHIL. \& POL., Autumn 1986, at 15, 16-24. Employing a form of act-utilitarianism, Regan assumes that "an act is right if and only if it produces at least as good consequences throughout the universe as any other act available to the agent." Id. at 15 .

9. Id. at 27-28. 
that it encourages a detached (cynical) view toward the law. Although I will not pursue the point further in this Essay, this position cannot be dismissed out of hand. Thoughtful and norally conscientious people who subscribe to the view that there is a moral obligation to obey the law might conclude that they do not want to habituate theinselves to disregard the law by readily substituting their own judgments of social convenience for those of the community. ${ }^{10}$

Joseph Raz, another conteniporary writer who contends that there is no moral obligation to obey the law, adopts much of Smith's argument, which Raz describes as "very powerful and persuasive."11 Raz also stresses the example of the countless traffic and "sinall tax offenses"12 that are never detected-offenses that one knows in advance will never be detected. The most that Raz will accept is that, in addition to the prudential reasons to obey the law, sonietimes we night have independent nioral reasons to obey the law. ${ }^{13}$

In his now voluminous writing on the subject, ${ }^{14}$ John Simnions contents himself with attenipts to show that a moral obligation to obey the law caimot be derived froni any of the following sources: consent (because niost people never give it and tacit consent does not anount to consent), the principle of fair play, considerations of gratitude, or the natural duty of justice. Because Simmons believes that these exhaust the possible sources of a moral obligation to obey the law, he concludes that there is no moral obligation to obey the law. ${ }^{15}$

10. One might note Aristotle's position that the habit of obedience to the law is itself a good. Aristotle, Politics, bk. II, ch. 8, at 1269a 11. 10-28 (W. Ellis trans. 1928). If Regan were to concede this point (and he might, because, as he points out, in a less than perfect world, a person might be mistaken as to the social desirability of his obeying the law, Regan, supra note 8, at 29), then, to guard against this danger, the temptation to equate legal obligations and moral obligations might arise even in a less-than-perfect society. For example, Regan concedes that one can have a inoral obligation to act in the manner indicated by morally just laws. Id. at 16. Accordingly, a person who does not want to be the sort of person who, like some who surrounded Presidents Nixon and Reagan, believes that there is no nced to obey the law when he cannot see the point of the law or when he fecls that the reasons underlying the law are not present, could conclude that, if a law is morally justifiable, he has a moral obligation to obey that law, except in circumstances in which it is clear that obedience would generate a larger social evil. If this is conceded, and if one is prepared to accept that the society im which he lives, although not ideal, is on the whole a morally good one, would one not have a moral obligation to behave in the way indicated by the laws of that society unless one could clearly conclude that some particular law was not directed toward the social good?

11. J. RAZ, AUTHORITY, supra note 1, at 233 n.l.

12. Id. at 238.

13. See id. at $237-42$.

14. See A. Simmons, Moral Principles, supra note 1; Simmons, Consent, supra note 1; Sïnmons, Voluntarism, supra note 1.

15. Mention also inight be made of Kent Greenawalt, who agrees that there is no general moral obligation to obey the law. In contrast to most of the other writers whom I have mentioned, how: ever, Greenawalt believes that, for a number of reasons including those that arise from the duty of 
Arrayed against this impressive list of scholars are a few figures, largely British, who gallantly maintain that there is indeed a general moral obligation to obey the law. Tony Honore finds the basis of this obligation in necessity-necessity in the sense that an individual has no option but to belong to a political society and, therefore, of necessity is put into a situation in which he lias duties to his fellow citizens. ${ }^{16}$ J.L. Mackie concedes that the moral obligation to obey the law cannot be derived from any more basic moral obligation. ${ }^{17} \mathrm{He}$ concludes that the obligation to obey the law is an independent moral obligation. Philip Soper, an American, derives the obligation to obey the law from our obligation to show respect for the good faith efforts of our political leaders to perform their duties. ${ }^{18}$ Finally, in more recent work, A.D.M. Walker contends, contra Simmons, that a moral obligation to obey the law can be derived from obligations of gratitude-obligations ultimately "owed to [our] fellow citizens collectively."19

As this brief description of the contending positions illustrates, the debate consists in large measure of assertions and counter-assertions that

fair play, one can be morally obligated to obey a large number of laws on a large number of occasions. Greenawalt, The Natural Duty to Obey the Law, 84 Mich. L. REv. 1 (1985); Greenawalt, Promise, Benefit, and Need: Ties That Bind Us to the Law, 18 GA. L. REv. 727 (1984); See also K. GREENAWALT, CONFLICTS OF LAW AND MORALITY 47-203 (1987) (analyzing a number of reasons for obeying the law including political autliority, social contract, utilitarianism, and fair play). For discussion by other proponents of the view that there is no general moral obligation to obey the law, see A. Woozley, LAW ANd Obedience: The ARguments of Plato's Crito (1979); Lyons, Need, Necessity, and Political Obligation, 67 VA. L. REv. 77 (1981).

16. Honoré, Must We Obey? Necessity as a Ground of Obligation, 67 VA. L. REV. 39 (1981). Honoré's suggestion that a person lias a moral obligation to obey the law led David Lyons to exclaim in an emotionally cliarged passage:

I do not see why a citizen or noncitizen miglit be supposed to have a moral obligation to promote genocide, to maintain slavery, or to do anything of the sort. ... Why must we be asked to suppose that our moral obligations may routinely require us to be instruments of injustice?

Lyons, supra note 15 , at 77.

17. Mackie, Obligations to Obey the Law, 67 VA. L. Rev. 143, 143-51 (1981).

18. See P. SOPER, A THEORY OF LAW, supra note 1.

19. Walker, Political Obligation and the Argument from Gratitude, 17 PHIL. \& PuB. Afr. 191, 196 (1988). Walker's conclusions are attacked on the ground that obligations based on gratitude are too weak, and thus too easily overridden, to generate an obligation to obey the law even of a just society. See Klosko, Political Obligation and Gratitude, 18 PHIL. \& PUB. AfF. 352 (1989). Walker's response is that it lias not been slown that all obligations of gratitude are weak and easily overridden. Walker, Obligations of Gratitude and Political Obligation, 18 PHIL. \& PUB. AfF. 359 (1989). In this regard, one might even note Ronald Dworkin's intriguing suggestion that, in what lie calls a "true community," which can be a large modern state, the obligations of the members of that community arise from their having received the benefits of community. See R. DwORKIN, LAw's EMPIRE 167-216 (1986). To give Klosko lis due, it should be noted that, in lis latest work, he is prepared to recoguize a general moral obligation to obey the law based on notions of fairness. Klosko, The Moral Force of Political Obligations, 84 AM. PoL. SCI. REv. 1235 (1990). For a discussion of Dworkin's lengtly argument, see Christie, Dworkin's Empire, 1987 DuKe L.J. 157, 168-71. 
often do not really come to grips with the arguments of the other side. A successful argument against the view that there is no moral obligation to obey the law must confront more directly the detailed arguments of those who take this view. In the succeeding pages, this is what I intend to do.

\section{What View of Morality Is Presupposed in the Debate?}

There is a curious feature to the controversy over the existence of a general moral obligation to obey the law: All the protagonists are prepared to assume that the average person does indeed beheve that there is a moral obligation to obey the law. Those writers who assert that, in point of fact, there is no such obligation obviously are asserting that the average person is simply wrong. But, when such distinguisled and able philosophers of law declare that there is no moral obligation to obey the law, the first question that immediately comes to mind is what do these writers mean when they talk about morals and moral obligations? What is their view of the nature of morahity? Do they espouse soine sort of natural law position that points to a universal and essentially unchanging moral umiverse? Or do they merely assune that Western society (and particularly American and British society) is characterized by the broad general acceptance of the particular morality-a conventional morality if you will-that forms the background to their writings? Or are these writers among those for whom morality is purely an individual affair? ${ }^{20}$ They obviously cannot be proceeding from the position that morality is only a personal matter, because then their thesis is one of little significance. At most-they then would be telling us that, under their own personal morality, there is no moral obligation to obey the law. To express the matter more pithily, they would be announcing that they themselves do not recognize any moral obhgation to the law. This would be an interesting bit of biographical information, but nothing more.

One would also not be inclined to interpret these writers' arguments as prennised on soine sort of natural law position. This is not merely because the conclusion that there is no general moral obligation to obey the law is the antithesis of one of the most frequently propounded propositions of the natural law tradition, but also because such an assuniption does not fit well with their writings and with what we know of then personally. One plausible conclusion, and the one most consistent with their method of argumentation, is that these writers are assuming the existence of a widely accepted set of social conventions-a positive no-

20. The questions of what is morality and of what it is to have a morality are difficult ones. See W. Frankena, What Is Morality?, in Thinking About Morality 3-40 (1980) (discussing the various uses of the terms "moral" and "morality" and the difficulty these cause in coming to grips with underlying concepts). 
rality, if you will-that provides the social cement that holds Western civilization together and legitimates the political and legal institutions which that civilization has generated. This conclusion is the one most consistent with their method of argumentation because they typically assume an audience that shares a substantial agreement on moral principles, as well as a shared common reaction to specific factual situations.

There is, of course, at least one other view of inorality that might be taken by those who deny the existence of an obligation to obey the law. A person miglit construct what he is prepared to admit is largely a personal inorality, and yet for him this inorality would be a universal one, in the sense that he is prepared to assert that all liuman beings sliould subscribe to his morality. Epistenologically, with its claim to universality, such an ideal inorality would resemble a morality premised upon a natural law, albeit possibly one witl a content different from moralities derived froin traditional natural law theories. In the context of the present discussion, such a person would be telling or urging our hypothetical average citizen to change his morality. But, whatever the morality to which they personally subscribe, the previously discussed writers have presented arguments that they believe will be. accepted by the average person as consistent with the morality he now sliares with his fellow liunian beings. The argument is not framed in terms of urging the average person to adopt a new morality. Furthermore, even if one were prepared to reinterpret these writers as actually inaking this more radical type of appeal, it would not immunize them from the criticism that arises from their distinction between general moral obligations to obey the law and other general moral obligations, such as the obligation to keep promises. $^{21}$

I am prepared to accept the assumption that there exists a set of social conventions that constitutes the positive morality that holds together and legitimates the political and legal institutions of Western civilization. The ultimate question, therefore, is whether the conclusions that I cliallenge are derivable from this widely accepted premise. The

21. See infra Part VI. Out of an excess of caution I also would like to anticipate the argument of an act-utilitarian like Donald Regan, who might assert that it is not merely that one has no general moral obligation to obey the law but that one has no general moral obligation to do anything. First, as already noted, Regan believes there is never a moral obligation to obey the law merely because it is the law. This makes obedience to law different from other sorts of activities in which Regan is, for practical reasons, prepared to use a "simplified procedure" of decisionmakingwhat other people might call "rules of thumb." See D. Regan, UtiLrtarianism AND Co-operaTION 171 (1980). Second, of course, these simplified procedures or rules of thumb are not too dissimilar from what often are called "prima facie moral obligations" and which I have called simply "moral obligations." Not only is Regan not prepared to accept obedience to law as something like a "rule of thumb," he also rejects it as a moral reason. Obedience to law is thus not like harm to others, which is a "moral reason." See Regan, supra note 8, at 28-29 and passim. 
argument must proceed carefully. Indeed, the emotionally compelling nature of the subject inatter inclines people to try to get immediately to the heart of the matter, rather than proceeding step by step and examining more fully many of the preconceptions they consciously or unconsciously use to underpin their arguinents. In the next Part, I shall therefore examine one point that needs substantial clarification if the argument over whether there is or is not a moral obligation to obey the law is going to proceed beyond the stage of mere assertion and counter-assertion-the nature of the relationship between law and inorality.

\section{The Supposed Clarity of the Separation of LaW and MORALITY}

It is now widely accepted that it makes sense, from an analytical point of view, to separate moral and legal questions. The writers whom I have inentioned go one step further, and assume that morality and law can be clearly distimguished and that, insofar as inorality and law interact, it is always morality that informs the law and not law that informs morality. Thus, it is frequently asserted that a moral obligation to obey the law is unnecessary because, as to important matters, there already exists a moral obligation to behave in the way in which the law directs. As to unimportant matters, the law serves the function of coordinating human activity, and we have many reasons independent of morality for wanting to conform to schemes of social cooperation that benefit ourselves. ${ }^{22}$ Indeed, there are means other than law to achieve such coordination. According to this thesis, whether such coordination is provided by law or custoin or public exhortation is a matter of indifference. ${ }^{23}$

22. These are among the most prominent arguments made by Joseph Raz; see J. RAZ, AUTHORITY, supra note 1, at 233-49. He repeats them in Raz, Obligation to Obey, supra note 1, at 9, 139. See also Smith, supra note 2 , at $\mathbf{9 7 4 - 7 5}$ (stating that morality is a concern when a law is violated only when the act is thought to be wrong on grounds other than illegality).

A critical reader of an earlier draft of this Essay has argued that, as a method of social coordination, law always has some negative moral value-which counts heavily against there being a general moral obligation to obey the law-because it is coercive. Leaving aside that people like St. Thomas Aquinas thought that the fact that law operated by way of coercion was a factor that increased the moral utility of law, see SUmma Theologica pt. II, Ist pt., at Question 92(2), Question 95(1) (Fathers of the English Dominican Province Trans. 1920), are we to conclude that it is a negative moral feature of many branches of Christianity that they assume a God who will punish transgressors? Are the claims of conscience less morally valid because they are backed up by punishment in the form of feelings of guilt? Of course no one would assert that the fact that the law regulated through the use of sanctions should not be a factor that a rational legislator would take into account in deciding whether it is desirable to regulate behavior through the use of law. But that is a different point.

23. To this last point, one might reply, as John Finnis has, that the fact that social convention or moral exhortation has not been able to solve various problems of social coordination now regulated by law shows that law is not simply a means of solving a social coordination problem that 
Is it really true, however, that, with regard to morally important matters, the law merely provides an additional nonmoral reason to behave in a specified fashion? To so conclude assumes either that there cannot be more than one moral reason to perform an act or that certain sorts of reasons to act (such as a preexisting legal obhigation) carmot serve as moral reasons to act. The latter assumption, of course, assumes away the problem. The former assumption fails to explain why there cannot be multiple types of moral obligations mutually reinforcing each other and multiple types of moral reasons for acting or refusing to act in a particular way. I shall return to this question in Part VIII of this Essay.

There is, however, an epistemologically more basic point that can be made here. The stark separation between law and morality-the assumption that the law does not affect morality-is simply untenable. In particular, I wish to assert that the prevailing public morality of any society is very definitely influenced by the law. ${ }^{24}$

No serious observer of American society over the past thirty years, and certainly no one who has spent a substantial portion of that time in the South, can have any doubt that decisions like Brown v. Board of Education $^{25}$ and federal civil rights legislation have profoundly influenced public perceptions as to the morality of segregation. Furthermore, notions as to what constitutes "theft," "fraud," or "steahing" are profoundly influenced by legal analysis-indeed, "tlieft" and "fraud" are legal terms of art. My argument, of course, is not that we should go to the opposite extreine and deny the force of morality in the law; instead, I wish to argue that the two are inseparable: It is a chicken-and-egg situa-

could be solved in another way. There often is no other way to achieve certain ends. See Finnis, The Authority of Law in the Predicament of Contemporary Social Theory, 1 NotRE DAME J.L. ETHICs \& PUB. POL'Y 115 (1984).

24. On a theoretical level, the Swedish legal philosopher Karl Olivecrona has strongly argued that, contrary to the popular supposition, law probably has a greater influence on morality than morality has on the law. K. Olivecrona, LAW As FAct 150-68 (1939). See also L. Fuller, $A$ Reply to Critics, in THE MORALITY OF LAw 204-07 (rev. ed. 1969) (rejecting the legal positivist argument that morality influences law to a greater extent than the converse by recoguizing that legal rules provide a vehicle for society to realize certain moral norms); L. FULLER, THE LAW IN QUEST OF ITSELF 135-37 (1940) (describing how Swedish legal thought has recognized that commnnal notions of right and wrong are shaped by the legal order and characterizing as a philosophical fiction the view that communal notions of morality dominate legal development); Golding, On the Idea of Moral Pathology, in Echoes fRom the Holocaust: PHILOSOPHICAL Reflections ON A DARK TIME (A. Rosenberg and G. Myers eds. 1988) (agreeing with Fuller that the relationship between law and morality is not as legal positivists believe, but is one in which the influence of one upon the other is roughly equal). As Fuller and Golding point out, notions like property and marriage that play an important part in moral discourse would not make sense without a legal system to give them meaning and content.

25. 347 U.S. 483 (1954). 
tion. Many of the writers I have mentioned, for example, use the act of promising as an illustration of the kind of activity that generates moral obligations. Yet, in their often extended discussions as to when promises create binding moral obligations, they curiously fall back on the analysis used by lawyers to determine whether contracts are legally binding. To demonstrate that promises create inoral obligations in certam circumstances, these writers sometimies cite actual legal decisions and legal treatises, and they even cite the Uniform Commercial Code and the Restatement of Contracts. ${ }^{26}$ Some of them even expressly adopt the legal position that promissory obligations are ultimately created by the reasonable objective expectations of the other parties to the transaction and not by the actual subjective intent of the alleged promisor ${ }^{27}$ If the critics of legal obligation are telling us anything, it appears to be that if a promise creates a legal obligation, it also creates a moral obligation.

The example of promising also shows that the separation of morally significant matters (im which moral obligations supply the needed direction) from the problems of social coordmation in a complex world (in which law sometimes shows the way) is simply untenable. In a complex world, everything is a inatter of social coordimation, as the practice of promising demonstrates. The point can be made even more decisively by taking a situation that would appear to provide one of the paradigmatic examples of morahty, in and of itself, providing a sufficient basis of obligation, namely, the circumstances under which the killing of another human being is permissible. It is instructive to note that, when Raz discusses this situation, he talks of "laws prescribing behaviour which is morally obligatory independently of the law (e.g. prohibiting inurder,

26. See Simmons, supra note 1 , at $812-14$. Simmons cites the U.C.C. $\$ 2-302$ comment 1 , for the proposition that an agreement is not binding when a party to a contract, who has an unfair bargaining position created by another's vulnerability, takes unfair advantage of that vulnerability. Id. at 814 n.63. Simmons is trying to determme when a promise is unenforceable because it has been exacted unconscionably. Another example can be found in P. SOPER, A THEORY OF LAW, supra note 1 , at $65-74$, in which Soper uses legal paradigms to explain why an obligation to obey the law cannot be derived from notions of promise, estoppel, and unjust enrichment. To support his argument, Soper relies on the Restatement (SECOND) OF CONTRACTS. P. SOPER, A THEORY OF LAW, supra note 1, at 65-67 (citing RESTATEMENT (SECOND) OF CONTRACTS $\$ \$ 19,69$ (1)(a) \& comment e, $90 \&$ comment a (1979)). Finally, Jefirie Murphy, who is prepared to accept that neither promises nor consent can ground the obligation to obey the law, uses legal sources to explain moral notions such as consent and duress. See Murphy, Consent, Coercion, and Hard Choices, 67 VA. L. REv. 79 (1981); see also Becker, Hard Choices Are Enough, 67 VA. L. REv. 97 (1981) (using cases and treatises to argue that hard choices can invalidate an agreement for the same reasons that invalidate unconscionable agreements made under duress).

27. See Simmons, Consent, supra note 1, at 806 (arguing that one who has not been denied the opportunity to learn about conventions governing certain interactions, and could have at least asked about the rules governing the interaction before participating, is negligently ignorant and has entered a bimding agreement, despite the absence of any intention on his or her part to do so, based on the reasonable expectations of the other party). 
rape, libel, invasion of privacy)."28 These are, of course, legal terms of art, the use of which once again illustrates how law influences our inoral notions. I would submit that it is not absurd to look at the law concerning inurder and manslaughter as serving the purpose of providing the social coordination for the practice of killing. There is no society that $I$ know of, at least in the Western world, in whiclı the killing of another human being is morally wrong under all circumstances. For example, killing inay occur in self-defense, in the course of conducting a lawful but hazardous enterprise, in the course of maintaining civil order, or in conductimg a war. It may happen purely "by accident." What constitutes murder or manslaugliter, what counts as self-defense or unavoidable accident, are all notions of considerable complexity in which legal analysis informs our notions of what is inorally permissible perliaps as mucli as our notions of morality dictate what should be the content of the law. A motorist acquitted of vehicular homicide may very well use his acquittal of the criminal charge to support the assertion that le was not inorally at fault in the killing. This amounts to bringing legal excuse to bear on the determination of moral culpability-a common modern phenomenon.

A standard response to the argument I have just presented begins by admitting that even the law of murder solves a problem of social coordination. This response, however, distimginshes murder from an area suclı as the rules of the road, an area in which we are indifferent to tlie possible outcomes. Society is indifferent as to whether people drive on the left or the riglit side of the road; it is only important tliat some choice be inade and then strictly followed. According to this argument, the situation is otherwise when morally important inatters are involved.

One should not try to inake too mucl of this supposed distinction. First, even as to the rules of the road, the options are limited and constrained. Technical factors point to soine solutions as being better than others. ${ }^{29}$ At the same time, the content of the law regulating killing-let

28. J. RAZ, AUTHORITY, supra note 1, at 245.

29. When people traveled on horseback (or foot), a right-handed man, armed only with a sword or knife, would want to pass a possibly hostile approaching stranger on the left. It is also no idle coincidence that in medieval castles stairwells were constructed so that a right-handed man climbing up the stairs would find the wall on his right. In more peaceful times, given the convention of shaking hands with the right hand, it also makes sense to approach on-coming people from the left. Likewise, once the decision is made to drive on a certain side of the road, say on the right, the coming of automobile traffic might lead one to require pedestrians to walk on the left side of the road, that is, facing the vehicular traffic. For a case that involved just such a statute, see Tedla v. Ellman, 280 N.Y. 124, 127-29, 19 N.E.2d 987, 989 (1939). The change to having vehicular traffic pass on the right is also not an arbitrary one. In a world in which the hauling of goods and people in large animal-drawn wagons is important, there are certain "natural" constraints that, in the absence of a contrary custom that is too difficult to change, point to certain solutions as preferable. For example, a right-handed person driving a team of horses harnessed in pairs would want to position 
alone the law relating to the inore coinplex subject of ownership and possession of property-is not as constrained by underlying notions of inorality as is assumed. Not only does the law inform our inoral notions concerning inurder and theft, but inany important aspects of the legal and moral concepts of murder and theft easily could be different. This is true not only on a cross-cultural basis - euthanasia of the old or of infants with birtli defects, etc. - but also within an individual country, particularly a country of any size and in which the population lacks lomogeneity. For example, some states in the United States require a person who is not defending his loone to "retreat to the wall," so to speak, before he may use deadly force against a person who tlireatens him with deadly force. ${ }^{30}$ In a majority of the states, the law was, and perliaps still is, that one can stand his ground and kill his assailant. In botl groups of states, the law both reflects and infornis social morality. ${ }^{31}$

\section{The Argument From Examples}

In the writers whose views I have been examining, I not only find a lack of clarity about wliat is meant by morahty and a naive view of the interaction and imterdependence of morality and law, but $I$ also find their method of arguinentation surprisingly lacking in vigor. This may be because their conclusions seem to them so self-evident that it does not seem worthwhile to belabor the poimt. Their usual metliod of arguinentation is by the presentation of various cases that they assume almost all people would agree should be decided in a certain way. But deciding the case in this way contradicts other common assuinptions, such as the assumption that there is a moral obligation to obey the law. Thus it follows, these writers contend, that the naive presuppositions of the average person are mistaken. I should make it clear that I liave no objection to the use of casuistic methods in inoral or legal arguinent. I only object to tlie simplistic use of arguinent by example tliat substitutes assertion for proof. Let ine give three exainples.

himself astride or behind the left rear horse in order to be able to whip all the horses more easily. Thus situated, the driver naturally would want to pass on the right to be able to gauge the appropriate clearance for oncoming wagons. It is only with the coming of the automobile that the choice seems a matter of indifference.

30. See Restatement (SECOND) OF TORTS $\S 65$ (1965). See also King v. State, 233 Ala. 198, 171 So. 254 (1936). For an extended discussion of the common-law cases, see Perkins, Self-Defense Re-Examined, 1 UCLA L. REv. 133 (1954).

31. See W. Prosser, TorTs 110-11 (4th ed. 1971). Now that Professor Prosser has died, those continuing his treatise have raised the question whether one can continue to rely on the authority supporting the "standing one's ground" position. See W. KEEton, D. DobBs, R. KEETON \& D. OWEN, PROSSER AND KEETON ON THE LAW OF TORTS 127 (5th ed. 1984) (arguing it is unsafe to rely on past decisions permitting person attached to stand his ground and use deadly force, even to the extent of killing attacker). This regrettably may be wishful thinking. 


\section{A. The First Example: Positional Duties}

In arguing that there is no moral obligation to obey the law, John Simmons asserts that positional duties, such as the legal obligations imposed on residents and citizens, "do not have moral weiglt." 32 More generally, he suggests "that no positional duties establish anything concerning moral requirements." 33 One of the examples Simmons uses to support his claim that positional duties, such as the legal duties of residents and citizens, do not give rise to moral obhigations is the case of an "army medic who, with a tent full of wounded patients, wanders off to spend the afternoon in a Saigon bar." 34 To make the example germane to his claim-that moral duties do not arise by virtue of position-Simmons further stipulates that the medic "was inducted into the service against his will." 35 Simmons agrees that in "leaving the wounded to suffer and die" the hypothetical medic failed to fulfill not only his positional duty but also his moral duty. ${ }^{36}$ Simmons insists, however, that the two duties are always completely independent. In Simmons's own words:

$[\mathrm{H}] \mathrm{e}$ has a natural duty to help those in need where he can (with certain qualifications), a duty which is "non-positional." In this case, the army medic has a moral duty to perform the same acts he has a positional duty to perform. But this former duty is not a duty "to perform his positional duties." For anyone, not just an army medic, has precisely the same duty to help those in need (although his medical skills Inake him better able to help). The duty here is completely independent of the position and the scheme or institution which defines it. ${ }^{37}$

The suggestion that anyone in the vicinity of tle hospital has the same inoral duty to assist the sick and wounded as the army medic whose name has been placed on the duty roster is so counterintuitive that it is not worth discussing. I will restrict myself instead to the case of medically qualified people who are in the vicinity of the hospital. It is counterintuitive to contend that the army medic in question has no greater moral duty to assist the sick and wounded than these other medics. It is certainly hard for me to believe that most people would accept Simmons's assertions. Would we not allow someone who was on his way to meet his fiancee or even to have a drink at a bar to assert that our hypothetical army medic owed a greater moral duty to the sick and

\footnotetext{
32. A. Simmons, Moral Principles, supra note 1, at 17.

33. Id.

34. Id. at 18.

35. Id. at 19.

36. Id.

37. Id. at 19-20 (emphasis added).
} 
wounded than he did? ${ }^{38}$ One also might note that legally one is obliged to come to the assistance of people whom one has imjured even through no fault of one's own. This legal obligation does not cease if there are other people present who could just as easily or more expertly care for the imjured person. ${ }^{39}$ Position does make a difference. Simmon's example does not support his assertion that legal duties, as a type of positional duties, do not impose any kind of moral obligations, but, if anything, lends support to the contrary assertion.

\section{B. The Second Example: Moral Obligations and the Receipt of Open Benefits}

Let us turn now to another example of the unconvincing use of casuistic argument. Simmons, extending the argument of Robert Nozick and others, takes the position that one upon whom unasked-for benefits are thrust does not by virtue of the receipt of those benefits incur any moral obligation to those who provide the benefits. ${ }^{40}$ Only by consenting to the benefit scheme or by voluntarily accepting benefits provided by that scheme can we mcur any such moral obligation. Because Simmons is not prepared to accept that the receipt of a benefit is the same as the acceptance of a benefit, he distinguishes between benefits that are "readily available" and those benefits that are "open" in the sense that one cannot avoid receiving thein. ${ }^{41}$ Receipt of open benefits does not amount to acceptance. Reworking an example given by Nozick, ${ }^{42}$ Simmons discusses

38. Indeed, even if one finds Simmons' example convincing, one example would not suffice to prove that moral obligations never arise by virtue of position.

The problem in imposing a legal or moral duty to rescue upon third parties lies in determining how that third person inay discliarge this duty. Once a volunteer lias undertaken the obligation, he would be legally obliged to continue until his services were no longer needed, that is, until the injured person recovered or the volunteer was relieved by someone who was at least as able to denl with the injured person's situation as the volunteer was. The RESTATEMENT (SECOND) OF TORTS $\S 324$ (1965) atteinpts to alleviate this onerous obligation by permitting a volunteer to discontinue assistance if, by so doing, he does not leave the other person "in a worse position than when the actor took cliarge of him." The hittle authority on the subject does not clearly support this restriction of the volunteer's duty and, furthermore, relying on comment $g$ to $\S 324$, it has been leld that, once a person has becn removed from a position of danger, the rescuer will be liable for replacing the victim in a position of equal danger to that from which he was rescued. See Parvi v. City of Kingston, 41 N.Y.2d 553, 559-60, 362 N.E.2d 960, 964-65, 394 N.Y.S.2d 161, 165 (1977) (citing RESTATEMENT (SECOND) OF TORTS $\$ 324$ comment $\mathrm{g}$ (1965)) (once rescue has begun it must be performed with due care, and such duty cannot be fulfilled by placing such person im position of peril equal to that from which lie was rescued).

39. RESTATEMENT (SECOND) OF TORTS $\$ 322$ (1965).

40. See A. Simmons, Moral Principle, supra note 1 , at 118-36.

41. Id. at 129-32.

42. R. NOZICK, ANARChy, STATE, AND UTOPIA 93-95 (1974). Nozick gives several examples, including neighbors who set up a public address system to provide public entertainment and people who thrust books upon others. The Nozick example most germane to the one Simmons uses is 
two men, Oscar and Willie, who hive in a neighborhood in which all the other neighbors agree to begin a scheme under which, by their joint efforts, the neighborhood is made spotless and maintained in that condition. Oscar and Willie refuse to participate in the scheme. ${ }^{43}$ Oscar "hates neatly trimmed yards, preferring crabgrass, long weeds, and scraggly bushes." 44 Willie does not, but he also does not wish to engage in a clean-up operation or contribute any funds to the operation. Simmons thinks it is clear that no one would think that Oscar had any moral obligation-from considerations of fair play or otherwise- to this cooperative scheine organized by his neighbors. Simmons also concludes that Willie has no obligation to his cooperating neiglibors either: "[I]f ordinary feelings about obligations of fair play insist that he is more vuhierable [to the accusations and demands of his neighbors], those feelings are mistaken."45 Rather, Willie's situation is comparable to that of a salesman, Sam, who canvasses the neighborhood eight liours a day, but does not reside in the neighborhood. According to Simmons, no one would imagine that Sam had any duty to participate in tlee scheine, no matter how much Sam liked working in neat and beautiful surroundings. ${ }^{46} \mathrm{Sim}-$ mons assumes that his example coinpletely disposes of the naive initial assumptions of the ordinary person and leads us to accept his thesis that the mere receipt of open benefits generates no moral obligations. Simmons uses the exainples, of course, to support his assertion that the receipt of open benefits by citizens generate no moral obligations on their part to obey the law. There are, however, some variants of Simmons' example that place its persuasive power in some doubt.

Suppose the entire neighborhood were cut off from the rest of the city by civil war or natural calamity. All the neighbors except Oscar and Willie agree to try to preserve and restore the neighborlıod. By inassive efforts they succeed in establishing water and electrical supplies; they provide police protection to keep hostile outsiders from coming into the neighborliood; they make possible the distribution of food; they create a sea of tranquility in an ocean of cliaos. Most people would feel that both Oscar and Willie had a moral obligation to aid in the efforts of the community. Would the cominon view be mistaken? To support his argument, Simmons must insist tliat it is. If Simmons tries to accommodate

[i]f each day a different person on your street sweeps the entire street, must you do so when your turn comes? Even if you don't care that much about a clean street? Must you imagine dirt as you traverse the street, so as not to benefit as a free rider?

Id. at 94 .
43. A. Simmons, Moral Principles, supra note 1, at 133-35.
44. Id. at 133.
45. Id. at 135 (emphasis in original).
46. Id. at $134-35$. 
the common view by asserting that the benefits of this communal arrangement are not what he calls open benefits-whose receipt does not imply acceptance-but rather are benefits that Oscar and Willie have accepted, then he has given up the game, because many of the benefits provided by society are precisely those kinds of benefits that we cannot help but accept. Perhaps no moral obligations to political society-such as a moral obligation to obey its laws-arise out of considerations of fair play or gratitude, but the arguments provided by Simmons do not convincingly make the case.

\section{The Third Example: "Fussy Regulations"}

My last example of the unconvincing nature of the methods of reasoning employed in the debate over the existence of inoral obligations to obey the law is taken from M.B.E. Smith. Smith presents the following argument:

To begin, it seems very doubtful that there is, in the lawyer's sense, a prima facie obligation to obey the law. It is undoubtedly true that most instances of lawbreaking are wrong, but it is also true that many are not: This is because there are, as Lord Devlin once remarked, "many fussy regulations whose breach it would be pedantic to call immoral," and because some breaches of even non-fussy regulations are justified. Now, unless-as in a court of law-there is soine pressing need to reach a finding, the mere fact that most $A$ s are also $B$ does not, in the absence of evidence that a particular $A$ is not $B$, warrant an inference that the $A$ in question is also a $B$ : In order for this inference to be reasonable, one must know that virtually all $A$ s are $B$ s. Since, then, it rarely happens that there is a pressing need to reach a moral finding, and since to know merely that an act is illegal is not to know very much of moral significance about it, it seems clear that, if his only information about an act was that it was illegal, a reasonable man would withhold judgnient until he learned more about it. Indeed, this is not only what the fictitious reasonable man would do, it is what we should expect the ordinary person to do. Suppose we were to say to a large number of people: “Jones has broken a law; but I won't tell you whether what he did is a serious crime or inerely violation of a parking regulation, nor whether he had good reason for his actions. Would you, merely on the strength of what I have just told you, be willing to say that what he did was morally wrong?" I have condncted only an informal poll; but, on its basis, I would wager that the great majority would answer "I can't yet say-you inust tell me more about what Jones did." 47

It is hard to believe that anyone would find this argument helpful, let alone convincing. To begin witli, what is the relevance of the fact that many legal prohibitions can with propriety be called "fussy regulations"?

47. Smith, supra note 2, at 973-74. 
Much of morality, and particularly the public morality that we have been taking as the background to the debate about the moral obligation to obey the law, centers on what might be called trivia: for example, the trivial falsehoods we refer to as "white lies" and the appropriation of office supplies for personal use. That morality is important does not mean that all or even most of our moral obligations are important. The obligations do not cease to be moral obligations simply because they are unimportant. For many people the area of morality that might be stigmatized as "fussy" is greatly enlarged by the fact that to say that a society shares a common morality is not to say that all individuals in that society accept each and every precept of the so-called common morality. Much of a public morality is for most people an external given, like the law, and thus capable of seeming to them as inere fussy regulation of trivia rather than concerned with important matters. ${ }^{48}$

The major point that Smith wants to inake is that his example provides additional proof that, if we really thought about the matter, we would recognize that we do not have even what he calls a "prima facie" moral obligation to obey the law. By a prima facie moral obligation Smith means a moral obligation that may be overridden in particular circumstances. ${ }^{49}$ The fact that we are unable to say that Jones has done something "morally wrong," when all we are told is that he has "broken a law," is of course completely compatible with Jones' having, using Smith's terminology, a prima facie inoral obligation to obey the law he has broken.

Even if the law broken by Jones concerns "serious" matters, the mere fact that Jones has broken the law does not establish that Jones has done something inorally wrong. Under some conditions, even murder can be inorally justified..$^{50}$ We certainly can think of many situations in which violation of the law, including laws with substantial moral overtones, would not be considered morally wrong. Even though it is probably illegal for a private citizen to break into his neighbor's house because he (reasonably) believes that his neighbor is beating his wife, this does

48. At the end of this Essay, I shall return to this question because if has important implications for the argument that there is no moral obligation to obey the law. See infra Part VIII(B).

49. This notion of prima facie obligation is what I have called a "moral obligation," with the understanding that the mere fact that we have a moral obligation to perform some act does not mean that, on balance, it is our moral duty to perform the act.

50. This point is suggested by the film Fail-Safe (Columbia Pictures 1964). In Fail-Safe, the President of the United States orders the dropping of an atomic bomb on New York, where his wife and daughter are shopping, to convince the Soviet Union that the dropping of an atomic bomb on Soviet territory was in fact accidental. When the stakes are high enough, we are led to consider that the intentional killing (murder) of the innocent may be a moral necessity. The film was based on the book by E. Burdick \& J. WheELER, FAIL-SAFE (1962). 
not necessarily mean this act is morally wrong. It is not necessarily morally wrong, even though all might agree that we have not only a legal but also a moral duty not to break into our neighbor's house.

To return more directly to Smith's example, suppose people are asked, "If I tell you I have broken a promise but I won't tell you what the promise was about or anything else about the situation, would you say that I have done something morally wrong?" I would hazard the guess that most people would say that they did not know, that they would need more information. Such an answer would not prove that they did not recognize what Smith would call a prima facie moral obligation to keep their promises. It is hard to think of any action-even the killing of another-in which one can confidently say, to use Smith's form of argnment, "virtually all A's are B's"; that is, that virtually all cases of the killing of another are cases of immoral conduct. ${ }^{51}$

In short, insofar as the argument that there is no moral obligation to obey the law proceeds by appealing to our intuitions concerning certain paradigmatic cases, it is unconvincing. It is time to turn to arguments that rest upon principles and not merely on intuitions.

\section{An Examination of the Principles Used to Support the ARGUMENT THAT THERE IS NO GENERAL MORAL OBLIGATION TO OBEY THE LAW}

The common primciple accepted by writers such as Smith, Raz, and Regan is that if an act of disobedience to the law causes no harm (to others) and does not undermine social stability by setting a bad exainple-which is a type of harms to others-then the act is not inorally wrong inerely because it is in violation of the law. ${ }^{52}$ Thus, if one knows that no one is observing him and if his conduct will not cause any harm to others, one may run stop signs in the desert without violating any moral duties. ${ }^{53}$

51. Soper takes a different tack in criticizing Smith's example and argument. Soper subunits that Smith's example does not test our intuitions about the moral obligation to obey the law, but rather our intuitions about whether the acts proscribed by the law are the same acts that morality would proscribe. He suggests that the question Sunith should have posed to his hypothetical interlocutors is, ought Jones to come forward with an explanation as to why he behaved as he did? Soper suggests that Sinith would not win his wager were this the question posed. P. SOPER, A THEORY OF LAW, supra note 1, at 84-90.

52. See J. RAZ, AuthoRrTy, supra note 1, at 237-42; Regan, supra note 8, at 16-24; Sinith, supra note 2, at 956-60, 969-73.

53. Raz even suggests that compliance with the revenue laws can fall into the same category, $J$. RAZ, AUTHORITY, supra note 1 at 238, but although such derelictions are likely to go undiscovered and even sometimes are undiscoverable, no one can seriously argue, especially in a period of budget deficits, that a failure to pay one's taxes does not affect others. 
The fact that most violations of the law go unpunished and even undetected does not, of course, mean that one can be certain at the outset that his activities will be undetected. Certainly Colonel Oliver North thought his conduct in violation of the Boland Amendment would be undetected and would not harm any Americans. In fact, he thought he might be helping some Americans. The point is that ex ante one can never be certain that no one is looking or even that no police are around, as many people who have run red hights late at night or sped on deserted highways have learned to their chagrin. Moreover, even if it were true that one could often be reasonably certain that his violations of the law would go undetected, one could ask what kind of a world it would be if the general understanding was that each person is permitted to break the law if there is a reasonable certainty that no one will be harmed or be affected by this bad example. ${ }^{54}$ Although I do not think much of the principle, I will assuine that it states the correct moral principle that should guide our thinking about the law and see what implications that principle has not only for the law but also for morality itself.

Take the practice of promismg, which all the protagonists assume to be capable of generating moral obligations. One can think of many cases in whicl the failure to keep a promise harıns no one and will have no effect whatsoever on third persons. Consider, for example, the case of a person who has put flowers on his motlier's grave every Sunday for the past thirty-eight years. As this person is dying he asks a friend, who is alone with him in his lospital room, to promise to continue the practice as long as the friend lives. The friend gives the promise. After the death of the promisee, the promisor asks himself if he really wants to spend each Sunday traveling to and from a cemetery instead of watching, depending on the season, football, basketball, or baseball on television. ${ }^{55}$ The reader undoubtedly can supply even better examples.

The moral virtue of honesty provides other sets of useful examples. Imagine a person wlio volunteers to check another's message box while the other person is out of town and to phone him if any messages are received. The volunteer totally forgets about his offer. In point of fact, no messages are received during the absence, and when the person returns he thanks the volunteer for going to the trouble of checking his

54. Actually, that sort of principle would probably become each person is permitted to break the law if there is a reasonable certainty that no one will be harmed thereby.

55. A further example concerns a person who receives money from a dying person and promises to look after his dog. Suppose, as many people do maintain, that animals have no moral status. This example, suggested to me by Martin Golding, is of course more serious than the one I have presented in the text, but it is also more complex, which is why I relegate it to footnote status. 
box. The volunteer, inwardly einbarrassed but inortified at the prospect of revealing his derehiction, rephes, "Don't inention it."

Applying the principle accepted by writers such as Smith, Raz, and Regan, if a proposed action-such as breaking a promise or being dishonest-does not contravene a inoral obligation whenever the action will not harm soineone or in some way set a bad example for third parties, then one can conclude that there is not always a inoral obligation to keep promises or to tell the truth. This would hold even when there are no other countervailing inoral considerations that would militate in favor either of not keeping the promise or of not telling the trutl.

A critic might respond, "No, No. One always has a moral obligation to beliave morally, sucli as to keep one's promises and not lie, regardless of the absence of untoward effects on others. That is what inorality is all about. The breach of one's inoral obligations is always malum in se." 56 The obvious riposte to this malum in se argument is that altlough the law often regulates things that are adinittedly morally neutral-just as promising can be about inorally neutral matters-the purposeful violation of the law is always malum in se. The skeptical philosopher cannot respond, "No, it is not," because violations of the law: (1) often cause no one any harm; (2) often do not set a bad example; and (3) the absence of a harm or a bad example can often be known with reasonable certainty before one acts contrary to the law. The ordinary person who takes it as a given that there is a moral obligation to obey the law can counter with the argument I have just constructed-that the saine can be said about many obligations that are cominonly thought to be inoral obligations. It is no answer to assert that it is not pernissible to raise that arguinent against the moral obligations that arise from promising or froin the requirement of honesty. The ordimary person wants argument, not arbitrary stipulation.

56. I use the legal term of art "malum in se" because people like M.B.E. Smith and Joseph Raz seem fascinated by the distinction between actions that are mala in se and those that are mercly mala prohibita. See J. RAZ, AUTHORITY, supra note 1, at 247; Smith, supra note 2, at 972 . The distinction is one that, as I understand, students of the criminal law find less than useful. Does, for example, the legal prohibition against selling cigarettes to minors concern something that, to the modern mind, is malum in se or is such a prohibition merely about something that is malum prohibitum? These terms are hardly used at all in G. Williams, CRIMINAL LAw, ThE GENERAL PART: Liamility AND REFORMS (2d ed. 1961). Doubts as to the utility of the distinction and a suggestion that the distinction should be totally abandoned in certain types of cases are expressed in W. LA FAVE \& A. SCOTT, Criminal LAw 32-35 (2d ed. 1986). For an extended discussion that illustrates how very difficult it is to apply these concepts, see R. PERkins \& R. BOYCE, Criminal LAw 15-18, 880-96 (3d ed. 1982) (explaining that acts mala in se are outrages upon public decency and morals while acts mala prohibita include any act forbidden by statute but not otherwise wrong, but then recognizing that the distinction often turns on the penalty-i.e., whether the purpose of the penalty is primarily to punish or merely to enforce compliance). 
The point I am driving at is that one cannot conclude that a moral obligation does not exist on the grounds that the obligation is trivial and the consequences of the breach of that obligation liave no practical significance. Yet critics of a moral obhgation to obey tlie law often rest their argument on the triviality of many legal obligations. This point can be amplified by looking in greater detail at M.B.E. Smith's article. In the beginning lie clearly asserts his thesis that "those subject to a government .. . have no prima facie obligation to obey all its laws."57 The thesis is less clearly stated at the end of his article, but it is certainly implicit in his concluding remarks. Raz and Regan cite him with approval precisely for persuasively arguing that thesis. ${ }^{58}$ In the middle of his argument, however, he shifts his inquiry to the exploration of a different question, nainely "[D]oes the prima facie obligation to obey the law count as substantial[?]"59 $\mathrm{He}$ then concludes this different imquiry with the observation that, "if there is a prima facie obligation to obey the law, it is at most of trifling weight."60 To this conclusion one might respond, "So what else is new?" The argument only makes sense if obligations to keep promises or to tell the truth-which Smith treats as paradigms of moral obligations-are always serious obligations. But of course, this is not so. Many of the promises we inake relate to trivial subjects, and the consequences of their breach are often even more trivial. There is absolutely no basis for asserting that moral obhgations by and large concern more serious inatters than do legal obhgations.

\section{POSSIBLE SOURCES OF THE CONFUSION}

I think the problem underlying much of the writing that claims to establish that one has no general moral obligation to obey the law arises as follows: It is taken as self-evident that one is obliged to behave morally. This obligation is then interpreted to include a general obligation to keep one's promises and a general moral obligation not to lie, etc. Morahty is considered as a totality and is not broken down by considering the specific moral cliaracter of particular acts. When these writers turn to the law, however, they are not content with a broad precept--such as that one has a general moral obligation to obey the law-but instead focus upon the moral obligation to obey specific legal obligations in specific circumstances. Fair enough. What I assert is that if you apply the same technique to moral obhigations, not surprisingly, one arrives at the same results. People can make silly promises and even promises that it

57. Smith, supra note 2 , at 950 .

58. See J. RAZ, AUTHORITY, supra note 1, at 233 n.1; Regan, supra note 8, at 15.

59. Smith, supra note 2 , at 971.

60. Id. 
would be immoral to keep; that does not mean that it makes no sense to talk of a general moral obligation to keep one's promises.

Some people assert, perhaps in an effort to ineet this problem, that legal and moral obligations are different in kind, that there are certain logical differences between moral obligations and legal obligations that preclude the possibility of there being a moral obligation to obey the law. Regan suggests that the inoral obligation to obey the law must be constant in all cases. If it is not (and clearly it is not), then the moral obligations that often are created by legal obligations cannot "sensibly [be] regarded as instances of a general inoral obligation to obey the law." 61 In making his arguinent, Regan proceeds froin the premise that "illegality does not coine in degrees." 62 Since illegality does not come in degrees, then neither can there be any variation im the inoral obligation generated by the legal obligation. I submit that this type of argument does not im any way show that there cannot be a general moral obligation to obey the law. If one approaches the question of moral obligation on a more general level, such as the obligation to follow the rules of morality or just the obligation to behave inorally, then the same sort of analytical problem is created as was noted in the context of legal obligation. The keeping of promises, like illegahity, does not "coine in degrees," but that does not inean that the inoral obligations which promises generate all have the same weiglit. To restate the argument in universal terms, the general obligation to behave inorally can be presumed always to be the saine, as with the general moral obligation to obey the law, but the strengtli of the moral obligation to do soine particular act-i.e. to fulfill a moral obligation in a particular set of circumstances-can and will vary. The fact that these particular obligations will vary in strength does not in any way entail that there is no general obligation (of constant strength) to behave inorally.

A possible partial response to iny argument thus far involves the concession that the general inoral obligation to behave inorally is no more variable than the general legal obligation to obey the law. Still, this response continues, the inoral obligation to perform particular acts var-

61. Regan, supra note 8 , at 24-25.

62. Id. at 24. Regan's argument was perhaps influenced by David Hume's contention that justice cannot be a natural virtue, but is rather an artificial virtue, because natural virtues fade into each other by "imperceptible degrees" whereas the obligations of justice are inflexible and discreet. D. Hume, A TREatise OF HUMAN NATURE, bk. III, pt. II, sec. VI, at 526-34 (L. Selby-Bigge ed. 1978). Hume, of course, is not arguing that the obligations of justice, which he often equates with legal rules, are not moral obligations, but merely that they arise from human convention. Furthermore, he exaggerates the inflexibility of law and ignores the fact, as we shall discuss infra, that insofar as one is talking about a shared public morality, however much that morality is based upon natural inclinations, it is not as fluid as Hume suggests. 
ies, whereas there is no variation in the legal obligation to perform the particular acts prescribed by law. To uny mind, this contention is not self-evidently true. It appears to be premised, ultimately, upon the mistaken view that the inoral obligation to obey the law, if it exists, must be the same as the moral obligation to obey any particular law. There is no obvious reason why this conclusion must follow or even that the various legal obligations to obey particular laws must all liave tlie same weight. Indeed, if one looks at the legal system as a totality, it is not at all clear that all legal obligations liave the same weight. ${ }^{63}$ Not only do different laws have different penalties annexed to their breacli, but soine laws are unenforced by prosecutors or unenforced in certain situations. Further, juries can refuse to convict, and judges can use tlieir discretion to impose suspended sentences or other minimal penalties. ${ }^{64}$

Even if it were true tliat legal obligations are always invariant in strengtli, that does not necessarily inean that there is no general moral obligation to obey the law or that there cannot be various degrees of moral obligation to obey particular laws. One is not obliged to defend the position that the moral obligation to obey a particular law and the legal obligation to obey tliat law are of equal intensity. Nor is the critic's case, for the proposition that there is no general moral obligation to obey the law, strengthened if lie starts from thie premise tliat there is no general moral obhigation to behave morally and that all moral obligations relate to particular acts (or instances of inaction) and therefore vary in strengtli. If one accepts this contention, the ouly conclusion that follows is that it is as meaningless to talk about a general moral obligation to obey tlie law as it is to talk about any other general moral obligation. This analysis does not rule out the existence of moral obligations, of various intensities, to obey the particular laws of the legal system.

\section{A Response to the ARgument that there is No Practical Need for a Moral Obligation to Obey THE LAW}

\section{A. The Principal Response}

The traditional view that there is a moral obligation to obey tlie law also lias been attacked, as I liave already noted, ${ }^{65}$ on tlie ground that it is not essential to cominunal life. This contention presupposes that once

63. I leave aside the easy case when legal obligations conflict and one legal obligation must inevitably prevail over the other.

64. See M. Kadish \& S. KADISH, Discretion To Disobey 45-72 (1973) (examining justifications for jury departure from judges' instructions).

65. See supra text accompanying note 22 . 
one has a moral obligation to do something, from a moral perspective, that is the end of the matter. To state the most extreme case, suppose a world in which the legal system tracked the public morality of that society; that is, there was no legal obligation that was not already publicly identified as a moral obligation. From the point of view of morality, it would then be asked, what does the law add? By providing sanctions and an enforcement mechanism, it nay make moral prohibitions more effective, but that is another matter. This method of analysis, by oversinplifying, grossly distorts the nature of morality. The arguinent suggests that one has no moral obligation to keep one's promises because one can conceive of a world in which, for other moral reasons, one already was under a moral obligation to behave exactly as one had pronised.

The argument fails. In the real world, of course, people are confronted with multiple and often competing moral obligations. In any given situation, a moral obligation to keep promises can compete with a moral obligation to refrani from harming others or to contribute to the common good. The moral obligation not to he can conne into conflict with inoral obligations of loyalty or the moral obligation to refrain from harming others or even with the moral obligation to keep one's promises. As we all know, we often find ourselves in circumstances in which we should not keep our promises or tell the trutl1. ${ }^{66}$ What we ought to do in any given situation depends on the balance of moral considerations. The fact that we inay already have a moral obligation to do something does not mean that, from the point of view of morality, nothing is added when the same action is made the subject of a legal obligation. In a situation in which we are confronted with conflicting moral obligations, the fact that we are under a legal obligation to choose one particular line of action may, from the moral perspective, without regard to the sanction inposed by the law, tip the balance in favor of that particular line of action.

In the real world, moreover, people soinetimes fail to fulfill their moral obhigations not because of competing moral considerations but merely because of laziness, perverseness, or countless other noninoral reasons. It is not absurd to recognize that, in addition to potential sanctions, the law also can add sufficient additional moral force to an existing obligation to overcome a person's moral inertia. ${ }^{67}$

66. We are all familiar with examples in which a person (A) who categorically maintains he would never lie is asked what he would do when a person (B) who is known to be bent on killing A's mother comes to the A's door and asks, "Is your mother in the housc?" If the poor woman is in the house, should $\mathrm{A}$ answer yes? Plato gives an analogous example involving the return of property to its rightful owner. See Plato, Republic bk. I, at 331C (A. Blooin trans. 1968).

67. We have been assuming a world in which every legal obligation exactly mirrored a preexisting moral obligation. In such a world it would not necessarily be the case that every moral obligation had its counterpart legal obligation. That is why a conflict between two moral obligations 


\section{B. Some Additional Observations}

I have presented my argument against the view that there is no general moral obligation to obey the law in a form that would be valid even on the assumption that each member of Western society has internalized the public morality of his society and even if each such person's "personal" morality exactly coincides with his society's public morality. In point of fact, this is rarely, if ever, the case-particularly in a heterogeneous and pluralistic society. Not only are there likely to be differences between soine aspeets of the public morality and each individual's personal morality, but, from the individual's point of view, there are likely to be rigidities and gaps in the public morality of his society, whereas his personal morality allows for infinite gradations and has the capability of generating individual solutions for each umique situation.

The distinction between an externally imposed set of norms and an internally accepted set of norms that various writers have tried to use to separate legal obhigations from moral obligations and to make plausible the argument that there is no moral obligation to obey the law will of course reappear when public morality is compared to personal morality. Following the structure of their arguments, people would never have a general personal moral obligation to fulfill the obligations imposed upon them by the public morality of their society even if in general they accept and approve of that public morality. The question of whether they did have any such personal moral obhigation could not arise unless they had internalized the specific norm of public morality that was in question or had accepted, as part of their own personal morality, an obligation to obey all the norms of public morality. If such people had accepted the latter obligation as part of their personal morality, then presumably the writers we have been discussing should urge these individuals to renounce any such obligation-just as they have urged us to reject a moral obligation to obey the law-except when violating a norm of public morality would harm others or otherwise set a bad example. Because accepting the difference between public morality and private morality greatly reduces the significance of these writers' arguments about the nature and extent of one's moral obligation to obey the law, I have pro-

would not necessarily also be a conflict between two legal obligations. As laard as it is to conceive of a world in which every legal obligation liad its counterpart independent noral obligation, I find it virtually impossible to conceive of a world in which every moral obligation lad its counterpart legal obligation. The argument I lave just constructed, however, namely that, by adding inoral weight, a general moral obligation to obey the law can overcome moral inertia due to laziness or whatever, shows that even in a world in which law and morality exactly mirror each other, it is possible for a general moral obligation to obey the law to serve a valuable moral function. 
ceeded on the assumption that public morality mirrors an individual's personal morality. 68

\section{CONCLUSION}

The arguments that purport to show that there cannot be a general moral obligation to obey the law all fail. If one does not have a general moral obligation to obey the law, it is not because one knows in advance that breaching a particular law will neither harm another nor otherwise affect third parties. Some other kind of proof is necessary. The other kinds of proof presented, based upon so-called examples, to refute the possibility of basing the moral obligation to obey the law on considerations of fair play, gratitude, natural duty, or some other basis are unconvincing. Given the failure of these arguinents, I am forced to conclude that if ordinary people believe that there is a moral obligation to obey the law, who is to say that they are wrong? Nor am I persuaded that we should want to say that they are wrong.

68. The reality of the difference between public and private morality seems incontrovertible. 